\title{
Dose-Dependent Effect of Coriander (Coriandrum Sativum L.) and Fennel (Foeniculum Vulgare M.) on Lead Nephrotoxicity in Rats
}

\author{
Shimaa El-Masry*, Hanem Abdel-Sabour Ali, Nora M. El-Sheikh, Safaa Mostafa Awad \\ Biochemistry and Nutrition Department, Faculty of Women for Arts, Science and Education \\ Ain Shams University, Cairo, Egypt \\ *shimaa_elmasry33@yahoo.com,elsheikh_nora@yahoo.com,safa2_mustafa@yahoo.com
}

\begin{abstract}
Nephrotoxicity is a complication due to the effect of some toxic chemicals on kidneys. Current study planned to screen the effect of coriander and fennel aqueous seeds extracts on lead-induced nephrotoxicity. Seventy-two adult male rats were equally divided to 6 groups: group (1) normal control, group (2) leadtoxicated rats were received $50 \mathrm{mg} / \mathrm{kg}$ b.wt of lead acetate by gastric tube daily, groups (3-6) were leadtoxicated and administered aqueous seeds extracts of coriander (250 and $500 \mathrm{mg} / \mathrm{kg}$ body weight/day) and fennel (100 and $150 \mathrm{mg} / \mathrm{kg}$ body weight/day), respectively. Lead-induced renal damage was evidenced by a significant elevation of serum and renal lead with reduction of serum delta amino levulinic acid dehydratase activity. Renal dysfunction was diagnosed by a significant elevation of kidney function tests accompanied with reduction in creatinine clearance. Results evidenced a significant increase of serum sodium and potassium concentrations and their depletion in urine. Renal oxidant-antioxidant balance was disturbed which evidenced by significant increase in renal malondialdehyde and nitric oxide and significant decrease in renal reduced glutathione, catalase, glutathione-S-transferase and superoxide dismutase activity. Treatment with coriander and fennel seeds extracts exerted a significant improvement of most of the biochemical parameters compared to lead group.
\end{abstract}

Keywords: lead; nephrotoxicity; coriander; fennel; rats.

Abbreviations: Lead (Pb), Glomerular Filtration Rate (GFR), Reactive oxygen species (ROS), Delta amino levulinic acid dehydratase ( $\delta A L A D)$, Renal nitric oxide (NO), Malondialdehyde (MDA), Superoxide dismutase(SOD), Reduced glutathione (GSH), Glutathione S transferase (GST), Catalase (CAT) and Phytic acid (PA).

\section{INTRODUCTION}

Nephrotoxicity is a major complication characterized by functional alterations including inhibition of protein synthesis, reduced glutathione depletion, lipid peroxidation and mitochondrial damage. Oxidative damage is thought to be one of the main mechanisms involved in nearly all chronic renal pathologies [1]. Exposure to chemical reagents like ethylene glycol, carbon tetra chloride, sodium oxalate and heavy metals like lead, mercury, arsenic and cadmium also induces nephrotoxicity [2].

Lead $(\mathrm{Pb})$ is a well-known multi-organ toxicant and it damage liver and kidney [3]. It is a divalent cation with a propensity to settle in the proximal tubule of the nephron, leading to nephrotoxicity. Lead accumulation in the proximal tubule leads to hyperuricaemia and gout, presumably by inhibiting uric acid secretion, and diminished glomerular filtration rate (GFR) [4].

Lead is known to cause oxidative damage in various tissues by bringing about imbalance in the generation and removal of reactive oxygen species [5]. It is known to cause free radical damage in tissues by two mechanisms: Increased generation of reactive oxygen species (ROS), including hydroperoxides, singlet oxygen and hydrogen peroxides, and by causing direct depletion of antioxidant reserves [6].

Many plants have been used for the treatment of kidney failure in traditional system of medicine throughout the world. Several herbs are prescribed for reducing renal damage and to avoid kidney related complications. These can be immense value in combating renal damage [7]. 
Coriander (CoriandrumSativum L.) belonging to family Umbelliferaeis widely distributed and mainly cultivated for seeds. It has been used as a flavoring agent in food products, perfumes and cosmetics [8]. It was shown that coriander extracts have phenolic compounds and flavonoids, suggesting that these compounds contribute to the antioxidative activity [9]. Coriander suppresses the deposition of lead by chelating the metal [10].

Coriander has been reported to exhibit several pharmacological effects such as antifertility, antiproliferative, anti-hyperlipidemic, digestive stimulant, hypotensive and antihyperglycemic [11]. Coriandrum sativum showed excretion of heavy metal in the urine of patients and also augmented the efficacy of antibiotics [3].

Fennel (Foeniculum Vulgare M.) is belonging to the family Apiaceae (Umbelliferae) with a characteristic aromatic odor. It is one of the most important medicinal plants grown within the Mediterranean region, in Europe and in Egypt [12]. Fennel seeds are generally eaten not only for the taste but also they are very healthy owing to the nutrition value attached to it. Fennel is also used for various health benefits that are derived from its anti-oxidants [13].

Fennel contains its own unique combination of phytonutrients-including the flavonoids rutin, quercitin, and various kaempferol glycosides-that give it strong antioxidant activity [14]. The major chemical components of fennel are flavonoids, polyphenols, carotenoids, minerals and vitamins [15].

Fennel used as carminative, digestive, lactogogue, diuretic and in treating respiratory and gastrointestinal disorders. Pharmacologically, fennel has been shown to possess anti-inflammatory, anti-diabetic, anti-bacterial, anti-fungal, anti-oxidant, analgesic, estrogenic, hepato-protective, antitumor activities. In addition, it is used as herbal medicine for kidney diseases [16].

So, this study aimed to investigate the dose-dependent ameliorative effect of coriander and fennel extracts on biochemical changes in serum and kidney tissue that occur in lead-induced nephrotoxicity in rats.

\section{MAterials AND Methods}

\subsection{Animals}

Adult male albino rats (Sprague- Dawely) weighing about 180-200 g were obtained from El-Salam farm, Giza, Egypt. Rats were kept individually in wire cages; they were fed on standard commercial pellets diet [17] and water ad libitum in acclimatization period (7 days) and also throughout all the experimental period (45 days).

\subsection{Plant Materials}

Coriander and Fennel seeds were purchased from local market in Cairo and were ground into a fine powder. The aqueous extracts of coriander and fennel were prepared as previously described by Kansal et al. [11] and Sadrefozalayi and Farokhi [18] respectively. 100g of coriander were added to $500 \mathrm{ml}$ distilled water and $100 \mathrm{~g}$ of fennel were added to $400 \mathrm{ml}$ distilled water. After $24 \mathrm{~h}$ maceration was done at room temperature $\left(37^{\circ} \mathrm{C}\right)$, the two mixtures were then heated for $30 \mathrm{~min}$ in the water bath at $65^{\circ} \mathrm{C}$, and then they were filtered, concentrated by heating over the water bath $\left(65^{\circ} \mathrm{C}\right)$ and dried by rotary evaporator. The two extracts (semi-solid pastes) were stored at $4{ }^{\circ} \mathrm{C}$ and used to treat animals as needed at doses: 250 and $500 \mathrm{mg} / \mathrm{kg}$ body weight/ day [3] for coriander extract and at doses: 100 and $150 \mathrm{mg} / \mathrm{kg}$ body weight/ day for fennel extract [19].

\subsection{Induction of Nephrotoxicity}

Lead acetate $\mathrm{Pb}\left(\mathrm{C}_{2} \mathrm{H}_{3} \mathrm{O}_{2}\right)_{2}$ was purchased from Sigma for chemicals company Cairo. Egypt. Nephrotoxicity was induced by giving rats lead acetate dissolved in distilled water at dose $50 \mathrm{mg} / \mathrm{kg}$ body weight/ day by gastric tube [20].

\subsection{Experimental Design}

Rats were divided into 6 groups of 12 rats each as follows:

Group 1 (Normal control): rats were received distilled water by gastric tube daily.

Group 2 (Lead-toxicated): rats were received $50 \mathrm{mg} / \mathrm{kg}$ b.wt of lead acetate by gastric tube daily.

Group 3 (Lead-toxicated + Low dose of coriander): rats were received $50 \mathrm{mg} / \mathrm{kg}$ b.wt of lead acetate and $250 \mathrm{mg} / \mathrm{kg}$ b.wt of coriander extract by gastric tube daily. 
Group 4 (Lead-toxicated + High dose of coriander): rats were received $50 \mathrm{mg} / \mathrm{kg} \mathrm{b.wt} \mathrm{of} \mathrm{lead}$ acetate and $500 \mathrm{mg} / \mathrm{kg}$ b.wt of coriander extract by gastric tube daily.

Group 5 (Lead-toxicated + Low dose of fennel): rats were received $50 \mathrm{mg} / \mathrm{kg}$ b.wt of lead acetate and $100 \mathrm{mg} / \mathrm{kg}$ b.wt of fennel extract by gastric tube daily.

Group 6 (Lead-toxicated + High dose of fennel): rats were received $50 \mathrm{mg} / \mathrm{kg}$ b.wt of lead acetate and $150 \mathrm{mg} / \mathrm{kg}$ b.wt of fennel extract by gastric tube daily.

\subsection{Handling of Urine, Blood and Kidneys}

After the last administration, animals from each group were kept in wire-bottom stainless steel metabolic cages for collection of 24-hour urine samples. Urine specimens were filtered to remove sediment debris and particles and then urine volumes were measured and recorded. Urine specimens were stored at $-20^{\circ} \mathrm{C}$ until analyzed for creatinine, total proteins, as well as sodium and potassium electrolytes.

At the end of the experimental period (45 days) and after overnight fasting, all rats were sacrificed and blood samples were collected from hepatic portal vein and portion of the blood was received into centrifuge tube and centrifuged at $1500 \mathrm{rpm}$ for $15 \mathrm{~min}$ for obtaining serum while the other portion was received into heparinized tubes and centrifuged for obtaining plasma. Serum and plasma samples were stored at $-20{ }^{\circ} \mathrm{C}$ for further assessment. Kidneys were separated immediately and washed by saline solution $(0.9 \% \mathrm{NaCl})$ then blotted on filter paper and weighed and then stored at $-20{ }^{\circ} \mathrm{C}$ for further assessment.

\subsection{Biochemical Assays}

Lead concentration in serum and kidneys tissue was determined by atomic absorption spectrophotometer as described by Subramanian[21], serum delta amino levulinic acid dehydratase $(\delta A L A D)$ activity was assayed by ELISA using kits from Glory Science co., USA, serum and urine creatinine were determined by colorimetric method kits and used for the calculation of creatinine clearance, urea was estimated by using Urease-Berthelot method kits, while uric acid was determined by enzymatic colorimetric kits and urinary protein was determined using Folin-Lowry colorimetric method kits, also serum and urinary sodium concentrations were measured colorimetrically using kits, but serum and urinary potassium concentrations were determined by turbidimetric method kits. Renal nitric oxide (NO), malondialdehyde (MDA) and Superoxide dismutase (SOD) were determined followed the colorimetric method kits, while reduced glutathione(GSH) were measured chemically according to Beutler et al. [22]. Finally, plasma and renal glutathione $\mathrm{S}$ transferase (GST) were measured by U.V method kits while catalase (CAT) activity was determined by colorimetric kits.

\section{STATISTICAL ANALYSIS}

The data was analyzed using the Statistical Package for Social Science program (S.P.S.S. 9). One-way analysis of variance (ANOVA) was used. The difference among groups means were tested using the least significant differences (LSD) at $(\mathrm{p}<0.05)$. Values were expressed as the Mean \pm SEM [23].

\section{Results}

In the present study, nephrotoxicity was successfully induced in rats by oral administration of lead acetate as indicated by a significant $(\mathrm{p}<0.05)$ increase in serum and renal lead concentration by 12.7 and 8.8 folds, respectively and reduction in serum $\delta$ ALAD by $74.61 \%$ comparing to normal control rats. Oral administration of coriander seeds extract at doses $(250 \& 500 \mathrm{mg} / \mathrm{kg}$ b.wt) and fennel seeds extract at doses $(100 \& 150 \mathrm{mg} / \mathrm{kg}$ b.wt)to lead- toxicated rats caused a significant decrement in the levels of lead in serum and kidney and elevation $(\mathrm{p}<0.05)$ in $\delta$ ALAD activity compared to leadtoxicated group (table 1).

High dose of coriander and fennel seeds extracts significantly $(\mathrm{p}<0.05)$ exhibited highly reduction in serum lead by $73.27 \%$ and $70.50 \%$, respectively and renal lead by $63.05 \%$ and $65.06 \%$, respectively, this dose dependent effect was not noticed for $\delta$ ALAD enzyme activity. 
Shimaa El-Masry et al.

Table1. Serum Delta Amino- Levulinic acid Dehydratase activity, serum and renal lead in the tested groups

\begin{tabular}{|c|c|c|c|c|c|c|c|}
\hline \multirow{2}{*}{$\begin{array}{c}\text { Groups } \\
\text { Parameters }\end{array}$} & \multirow[b]{2}{*}{$\begin{array}{l}\text { Normal } \\
\text { control }\end{array}$} & \multirow[b]{2}{*}{$\begin{array}{c}\text { Lead- } \\
\text { toxicated }\end{array}$} & \multicolumn{2}{|c|}{ Coriander- treated } & \multicolumn{2}{|c|}{ Fennel- treated } & \multirow[b]{2}{*}{$\begin{array}{c}\text { L.S.D } \\
(p \leq 0.05)\end{array}$} \\
\hline & & & $\begin{array}{l}\text { At dose } 250 \\
\mathrm{mg} / \mathrm{kg} \text { b.wt }\end{array}$ & $\begin{array}{l}\text { At dose } 500 \\
\mathrm{mg} / \mathrm{kg} \mathrm{b.wt}\end{array}$ & $\begin{array}{l}\text { At dose } 100 \\
\text { mg / kg b.wt }\end{array}$ & $\begin{array}{l}\text { At dose } 150 \\
\text { mg / kg b.wt }\end{array}$ & \\
\hline $\begin{array}{l}\text { Serum Delta } \\
\text { Amino- } \\
\text { Levulinic acid } \\
\text { Dehydratase } \\
\text { (ng/L) }\end{array}$ & $54.32 \pm 1.16^{\mathrm{a}}$ & $13.79 \pm 0.62^{\mathrm{c}}$ & $37.70 \pm 0.62^{\mathrm{b}}$ & $38.14 \pm 1.21^{\mathrm{b}}$ & $39.63 \pm 0.76^{\mathrm{b}}$ & $39.36 \pm 0.66^{\mathrm{b}}$ & 2.5 \\
\hline $\begin{array}{l}\text { Serum } \\
\text { lead } \\
(\mu \mathrm{g} / \mathrm{dl})\end{array}$ & $1.40 \pm 0.053^{\mathrm{d}}$ & $17.73 \pm 0.38^{\mathrm{a}}$ & $6.98 \pm 0.19^{b}$ & $4.74 \pm 0.22^{\mathrm{c}}$ & $7.24 \pm 0.22^{\mathrm{b}}$ & $5.23 \pm 0.20^{\mathrm{c}}$ & 0.65 \\
\hline $\begin{array}{l}\text { Renal } \\
\text { lead } \\
(\mu \mathrm{g} / \mathrm{g} \\
\text { tissue })\end{array}$ & $5.72 \pm 0.098^{\mathrm{e}}$ & $50.20 \pm 1.17^{\mathrm{a}}$ & $27.85 \pm 1.08^{\mathrm{b}}$ & $18.55 \pm 0.46^{\mathrm{d}}$ & $24.98 \pm 1.07^{\mathrm{c}}$ & $17.54 \pm 0.89^{\mathrm{d}}$ & 2.5 \\
\hline
\end{tabular}

Values are expressed as means \pm S.E., $n=12$

Means in a row without common letter are differ

The results represented in table (2) showed that lead-toxicated rats had a significant $(\mathrm{p}<0.05)$ increase in kidney function tests (serum creatinine, urea, uric acid and urinary protein) by $101.54 \%, 2$ folds, $84.31 \%$ and 2.7 folds, respectively accompanied with reduction in creatinine clearance by $72.06 \%$. Also a significant $(\mathrm{p}<0.05)$ increase of serum sodium and potassium concentrations by $17.33 \%$ and $83.67 \%$, respectively and their depletion in urine by $15.44 \%$ and $26.55 \%$, respectively was recorded.

Table2. Some kidney function parameters as well as sodium and potassium in serum and urine in the tested groups

\begin{tabular}{|c|c|c|c|c|c|c|c|c|}
\hline & \multirow{2}{*}{ Groups } & \multirow{2}{*}{$\begin{array}{l}\text { Normal } \\
\text { control }\end{array}$} & \multirow{2}{*}{$\begin{array}{c}\text { Lead- } \\
\text { toxicated }\end{array}$} & \multicolumn{2}{|c|}{ Coriander-treated } & \multicolumn{2}{|c|}{ Fennel- treated } & \multirow{2}{*}{$\begin{array}{r}\text { L.S.D } \\
(p \leq 0.05)\end{array}$} \\
\hline Parameter & & & & $\begin{array}{l}\text { At dose } 250 \\
\mathrm{mg} / \mathrm{kg} \text { b.wt }\end{array}$ & $\begin{array}{l}\text { At dose } 500 \\
\text { mg/ kg b.wt }\end{array}$ & $\begin{array}{l}\text { At dose } 100 \\
\mathrm{mg} / \mathrm{kg} \mathrm{b.wt}\end{array}$ & $\begin{array}{l}\text { At dose } 150 \\
\mathrm{mg} / \mathrm{kg} \text { b.wt }\end{array}$ & \\
\hline \multicolumn{2}{|c|}{$\begin{array}{c}\text { Serum creatinine } \\
(\mathrm{mg} / \mathrm{dl})\end{array}$} & $0.65 \pm 0.01^{\mathrm{c}}$ & $1.31 \pm 0.07^{\mathrm{a}}$ & $0.69 \pm 0.02^{\mathrm{c}}$ & $0.72 \pm 0.03^{\mathrm{bc}}$ & $0.80 \pm 0.03^{\mathrm{b}}$ & $0.70 \pm 0.02^{\mathrm{c}}$ & 0.096 \\
\hline \multicolumn{2}{|c|}{$\begin{array}{l}\text { Creatinine clearance } \\
(\mathrm{ml} / \mathrm{min} .)\end{array}$} & $0.68 \pm 5.29^{\mathrm{a}}$ & $0.19 \pm 1.50^{\mathrm{d}}$ & $0.37 \pm 2.42^{\mathrm{c}}$ & $0.47 \pm 3.23^{\mathrm{b}}$ & $0.47 \pm 3.78^{\mathrm{b}}$ & $0.47 \pm 3.91^{b}$ & 0.1 \\
\hline \multicolumn{2}{|c|}{ Serum urea $(\mathrm{mg} / \mathrm{dl})$} & $14.27 \pm 0.54^{\mathrm{e}}$ & $30.65 \pm 1.10^{\mathrm{a}}$ & $19.65 \pm 0.25^{\mathrm{bc}}$ & $17.59 \pm 0.26^{\mathrm{d}}$ & $21.25 \pm 0.45^{\mathrm{b}}$ & $18.82 \pm 0.74^{\mathrm{cd}}$ & 1.77 \\
\hline \multicolumn{2}{|c|}{$\begin{array}{l}\text { Serum uric acid } \\
(\mathrm{mg} / \mathrm{dl})\end{array}$} & $14.28 \pm 0.66^{\mathrm{c}}$ & $26.32 \pm 0.82^{\mathrm{a}}$ & $18.82 \pm 0.94^{\mathrm{b}}$ & $15.02 \pm 0.24^{\mathrm{c}}$ & $18.38 \pm 0.85^{\mathrm{b}}$ & $15.62 \pm 0.75^{\mathrm{c}}$ & 2.1 \\
\hline \multicolumn{2}{|c|}{$\begin{array}{c}\text { Urinary protein } \\
(\mathrm{mg} / \mathrm{dl})\end{array}$} & $90 \pm 1.35^{\mathrm{f}}$ & $243.91 \pm 5.23^{\mathrm{a}}$ & $183.11 \pm 2.85^{\mathrm{b}}$ & $140.20 \pm 1.86^{\mathrm{d}}$ & $155.64 \pm 1.03^{\mathrm{c}}$ & $121.91 \pm 1.79^{\mathrm{e}}$ & 7.73 \\
\hline \multirow{2}{*}{ Sodium } & $\begin{array}{l}\text { Serum } \\
(\mathrm{mmol} / \mathrm{L})\end{array}$ & $132.86 \pm 0.33^{\mathrm{e}}$ & $155.89 \pm 0.40^{\mathrm{a}}$ & $145.79 \pm 0.58^{c}$ & $140.83 \pm 0.81^{\mathrm{d}}$ & $150.0 \pm 0.39^{\mathrm{b}}$ & $144.51 \pm 0.45^{\mathrm{c}}$ & 1.46 \\
\hline & $\begin{array}{l}\text { Urine } \\
(\mathrm{mmol} / \mathrm{L})\end{array}$ & $137.53 \pm 0.89^{\mathrm{a}}$ & $116.29 \pm 035^{\mathrm{d}}$ & $121.01 \pm 079^{c}$ & $126.79 \pm 0.97^{b}$ & $125.67 \pm 0.53^{b}$ & $125.48 \pm 0.79^{\mathrm{b}}$ & 2.12 \\
\hline \multirow{2}{*}{ Potassium } & $\begin{array}{c}\text { Serum } \\
(\mathrm{mmol} / \mathrm{L})\end{array}$ & $8.82 \pm 0.18^{\mathrm{d}}$ & $16.20 \pm 0.18^{\mathrm{a}}$ & $10.32 \pm 0.11^{\mathrm{c}}$ & $10.51 \pm 0.08^{\mathrm{c}}$ & $11.64 \pm 0.24^{\mathrm{b}}$ & $10.31 \pm 0.21^{\mathrm{c}}$ & 0.49 \\
\hline & $\begin{array}{c}\text { Urine } \\
(\mathrm{mmol} / \mathrm{L})\end{array}$ & $78.97 \pm 0.74^{\mathrm{a}}$ & $58.00 \pm 1.02^{\mathrm{e}}$ & $68.46 \pm 0.70^{\mathrm{d}}$ & $74.89 \pm 0.26^{\mathrm{b}}$ & $71.81 \pm 0.65^{\mathrm{c}}$ & $72.96 \pm 0.61^{b c}$ & 1.98 \\
\hline
\end{tabular}

Values are expressed as means \pm S.E., $n=12$

Means in a row without common letter are differ 
Lead-toxicated rats administrated coriander or fennel seeds extract at the tested doses, significantly $(\mathrm{p}<0.05)$ showed a marked renal protection evidenced by amelioration in the kidney function tests. A significant $(\mathrm{p}<0.05)$ reduction in serum sodium and potassium levels and increase their excretion in urine are also noted comparing to lead-toxicated group. The highest doses of coriander and fennel seeds extracts significantly $(\mathrm{p}<0.05)$ exhibited more effectiveness in restoration of most kidney function tests and amelioration of sodium and potassium levels in serum and urine.

From table (3) it is obvious that, lead administration to rats caused disturbance in renal oxidantantioxidant balance evidenced by a significant $(\mathrm{p}<0.05)$ reduction in the levels of renal reduced glutathione by $69.16 \%$ and antioxidant enzymes activity as plasma and renal CAT and GST by $48.79 \%, 58.46 \%, 73.28 \%$ and $71.87 \%$, respectively also renal SOD was decreased by $78.85 \%$, with elevation of renal NO and MDA as compared to normal control group. The statistical analysis exhibited an elevation of renal GSH as well as antioxidant enzymes activity and reduction in renal levels of NO and MDA when lead-toxicated rats orally given coriander and fennel seeds extracts at the tested doses comparing to lead group.

Table3. Renal reduced Glutathione, plasma and renal antioxidant enzymes activity and renal nitric oxide and malondialdehyde in the tested groups

\begin{tabular}{|c|c|c|c|c|c|c|c|c|}
\hline \multirow{2}{*}{\multicolumn{2}{|c|}{\begin{tabular}{|} 
Groups \\
Parameters
\end{tabular}}} & \multirow{2}{*}{ Normal control } & \multirow{2}{*}{$\begin{array}{c}\text { Lead- } \\
\text { toxicated }\end{array}$} & \multicolumn{2}{|c|}{ Coriander- treated } & \multicolumn{2}{|c|}{ Fennel- treated } & \multirow{2}{*}{$\begin{array}{l}\text { L.S.D } \\
(p \leq 0.05)\end{array}$} \\
\hline & & & & $\begin{array}{l}\text { At dose } 250 \\
\mathrm{mg} / \mathrm{kg} \mathrm{b.wt}\end{array}$ & $\begin{array}{l}\text { At dose } 500 \\
\mathrm{mg} / \mathrm{kg} \text { b.wt }\end{array}$ & $\begin{array}{c}\text { At dose } 100 \mathrm{mg} \\
/ \mathrm{kg} \mathrm{b.wt}\end{array}$ & $\begin{array}{c}\text { At dose } 150 \mathrm{mg} \\
/ \mathrm{kg} \mathrm{b.wt}\end{array}$ & \\
\hline \multicolumn{2}{|c|}{$\begin{array}{c}\text { Renal Reduced } \\
\text { Glutathione (mg/g } \\
\text { tissue) }\end{array}$} & $75.16 \pm 0.86^{\mathrm{a}}$ & $23.18 \pm 0.97^{\mathrm{e}}$ & $48.26 \pm 1.41^{\mathrm{d}}$ & $49.98 \pm 1.90^{\mathrm{cd}}$ & $52.80 \pm 1.53^{\mathrm{c}}$ & $58.86 \pm 1.50^{\mathrm{b}}$ & 4.32 \\
\hline \multirow[t]{2}{*}{ Catalase } & $\begin{array}{c}\text { Plasma } \\
(\mathrm{U} / \mathrm{L})\end{array}$ & $1762.44 \pm 30.3^{\mathrm{a}}$ & $902.48 \pm 2.6^{\mathrm{d}}$ & $1002.07 \pm 10.9^{c}$ & $1170.5 \pm 34^{\mathrm{b}}$ & $981.53 \pm 17.0^{\mathrm{c}}$ & $1051.46 \pm 37.8^{c}$ & 72.2 \\
\hline & $\begin{array}{c}\text { Renal } \\
\text { (U/g } \\
\text { tissue) }\end{array}$ & $7.92 \pm 0.1^{\mathrm{a}}$ & $3.29 \pm 0.07^{\mathrm{d}}$ & $4.97 \pm 0.2^{\mathrm{c}}$ & $5.45 \pm 0.13^{b}$ & $5.35 \pm 0.24^{\mathrm{bc}}$ & $5.45 \pm 0.2^{\mathrm{b}}$ & 0.47 \\
\hline \multirow{2}{*}{$\begin{array}{l}\text { Glutathion } \\
\text { e }- \text { S- } \\
\text { Transferas } \\
\text { e } \\
\end{array}$} & $\begin{array}{c}\text { Plasma } \\
(\mathrm{U} / \mathrm{L})\end{array}$ & $677.72 \pm 9.1^{\mathrm{a}}$ & $181.08 \pm 2.2^{\mathrm{d}}$ & $313.70 \pm 5.27^{\mathrm{c}}$ & $504.4 \pm 11.22^{\mathrm{b}}$ & $479.69 \pm 10.8^{\mathrm{b}}$ & $505.44 \pm 12.04^{b}$ & 26 \\
\hline & $\begin{array}{l}\text { Renal } \\
\text { (U/g } \\
\text { tissue })\end{array}$ & $3.20 \pm 0.12^{\mathrm{a}}$ & $0.90 \pm 0.02^{\mathrm{c}}$ & $2.08 \pm 0.04^{\mathrm{b}}$ & $2.24 \pm 0.05^{\mathrm{b}}$ & $2.14 \pm 0.05^{\mathrm{b}}$ & $2.20 \pm 0.05^{\mathrm{b}}$ & 0.176 \\
\hline \multicolumn{2}{|c|}{$\begin{array}{c}\text { Renal Superoxide } \\
\text { dismutase (U/g } \\
\text { tissue) }\end{array}$} & $729.34 \pm 11.04^{\mathrm{a}}$ & $154.29 \pm 3.4^{d}$ & $483.7 \pm 18.78^{c}$ & $508.61 \pm 16.9^{\mathrm{bc}}$ & c $518.08 \pm 17.24^{\mathrm{bc}}$ & $524.38 \pm 12.90^{\mathrm{b}}$ & 40.56 \\
\hline \multicolumn{2}{|c|}{$\begin{array}{l}\text { Renal Nitric Oxide } \\
(\mu \mathrm{mol} / \mathrm{g} \text { tissue })\end{array}$} & $22.59 \pm 1.06^{\mathrm{e}}$ & $151.13 \pm 1.11^{\mathrm{a}}$ & $61.14 \pm 1.66^{\mathrm{b}}$ & $42.05 \pm 1.22^{\mathrm{d}}$ & $51.96 \pm 1.27^{\mathrm{c}}$ & $45.55 \pm 1.76^{\mathrm{d}}$ & 3.8 \\
\hline \multicolumn{2}{|c|}{$\begin{array}{c}\text { Renal } \\
\text { Malondialdehyde } \\
\text { (mmol/ g tissue) }\end{array}$} & $3.85 \pm 0.12^{\mathrm{d}}$ & $8.30 \pm 0.16^{\mathrm{a}}$ & $5.84 \pm 0.11^{\mathrm{b}}$ & $5.53 \pm 0.09^{\mathrm{bc}}$ & $5.60 \pm 0.09^{b}$ & $5.29 \pm 0.068^{c}$ & 0.315 \\
\hline
\end{tabular}

Values are expressed as means \pm S.E., $n=12$

Means in a row without common letter are differ

Dose-dependent effect was noticed in serum and renal lead, renal GSH and SOD by two doses of fennel and high dose of coriander seeds extract, in plasma CAT enzyme activity by high dose of coriander extract, and in renal catalase, NO and MDA by the high doses of coriander and fennel seeds extracts. 


\section{DISCUSSION}

In the current study, lead administration induced nephrotoxicity significantly $(\mathrm{p}<0.05)$ evidenced by elevation of serum and renal lead concentration with inhibition of serum $\delta$ ALAD activity. These results are in accordance with Manoj Kumar et al. [3] and Velaga et al. [24] SALAD is an indicator enzyme for lead toxicity and its activity is inhibited when lead binds to its active center. Lead toxicity increases the excretion of accumulated $\delta$ ALAD into the urine. The accumulated $\delta$ ALAD may autooxidize to - form reactive oxygen species and in this way induces lipid peroxidation [25]. The elevation of lead in kidney tissues is attributed to that the kidney may be a major target organ of lead toxicity, and that the epithelial cells of proximal convoluted tubules and Bowman's capsule seem to be more sensitive to lead induced nephrotoxicity. The proximal convoluted tubules are the primary sites of reabsorption and active transport leading to higher concentration of lead in the epithelial lining of these tubules [26].

Oral administration of coriander and fennel seeds extracts restored delta amino levulinic acid activity in lead-toxicated rats; this finding is in agreement with Kansal et al. [26] and Manoj Kumar et al. [3] who reported that natural herbs contain polyphenolic compounds acts as antioxidants which scavenge free radicals and thus regulate the level of $\delta$ ALAD enzyme activity. Also phenolic compounds potentiate the removal of lead by their metal chelating ability. Coriander may contain some chelating agent which has an affinity for the lead ion. Phytic acid (PA), a major phosphorus storage compound in most seeds and cereal grains, is known as a natural chelating agent. PA has strong ability to chelate multivalent metal ions result in the formation of very water-insoluble salts that are poorly absorbed from the gastrointestinal tract and consequently poor bioavailability [27]. Quercetin which present in coriander and fennel chelates lead by forming a coordination bond with the lead ions through its ortho-phenolic groups located on the quercetin B ring[28]. As well as, regulating the ROS level in the kidney of rats, which might be ascribed to its ability to scavenge and prevent free radical generation[29].

The present study declared a significantly elevation in all kidney function tests with reduction in creatinine clearance accompanied by increase in serum sodium and potassium concentration and decrease their concentration in urine in lead-treated rats. These results are confirmed with Suleman et al.[30]; Ramya and Prasanna [31] and Taha et al.[32]. Lead accumulation in kidney cause damage in renal tubules, decreasing the number of the functional nephrons which weakens the reabsorption process and generate reactive oxygen species which damage the cells leads to apoptosis, these adverse effects on renal function resulted in elevation of nitrogen containing compounds as urea, creatinine and uric acid in the blood, proteinuria and reduction in creatinine clearance.

The increased level of blood urea and creatinine concentration in lead-toxicated rats suggests the inability of the kidney to excrete these products causing their increase in blood and decrease their excretion in urine [33]. The increments in uric acid concentrations may be due to degradation of purines or to an increase of uric acid levels by either overproduction or inability of excretion as uric acid is the end product of the catabolism of tissue nucleic acid, i.e. purine and pyrimidine bases metabolism. The enhancement in the total urinary protein excretion is due to decrease reabsorption of low molecular weight proteins by injured tubules [34].

Chronic exposure to low-levels of lead resulted in electrolyte retention and elevation of sodium and potassium; this is due to lead effects on renal tubular transport mechanisms [35]. Another mechanism of increase sodium and potassium level is the decrease in functioning nephrons that trigger multiple adaptive processes in the hyper functioning remaining nephrons including augmented rates of electrolyte reabsorption [36].

A significant improvement in all kidney function tests and regulation of electrolyte concentration (sodium and potassium) in serum and urine were clearly evidenced after administration of coriander and fennel seeds extracts at the tested doses. These results are cooperated with Aissaoui et al. [37] and Saeed et al. [38]. The ameliorating effect of coriander and fennel seeds extracts on the kidney function biomarkers may be due to their diuretic, antihypertensive and naturetic effects resulting in increased renal blood flow and GFR, promoting water and potassium excretion and restoration of the daily rate of renal sodium excretion [37], [39].

Moreover, some active components which present in coriander and fennel seeds extracts, including flavonoids, polyphenols and carotenoids have an antioxidant, anti-inflammatory and free radicals 
scavenging activity [40]. Quercetin has ability to decrease arginine consumption in urea synthesis by inhibiting hepatic arginase makes arginine more available for the synthesis of proteins. Such effect would enhance renal regenerating capabilities, abolish the augmented tubular reabsorption of electrolytes by hyper functioning nephrons and decrease vascular resistance, thus improving renal blood flow and glomerular filtration rate [36].

A significant decrease in renal GSH as well as all antioxidant enzymes activities beside the increase of the renal levels of NO and MDA was noticed in lead-toxicated-rats. These results are confirmed with Liu et al [41]; Reddyet al. [42]; Elmendorf [43] and Manoj Kumar et al. [3].

Heavy metal depletes glutathione and protein bound sulfhydryl groups resulting in enhanced production of reactive oxygen species such as superoxide ions, hydroxyl radicals and hydrogen peroxide. These oxygen species resulted in lipid peroxidation [44].The changes in enzymatic antioxidant activity (CAT, GST, SOD) and non-enzymatic antioxidant (GSH)may be due to lead generation of ROS or by reducing the antioxidant cell defense system, depleting glutathione, inhibiting sulfhydryl dependent enzymes, interfering with some essential metals as copper needed for antioxidant enzymes or by increasing cell susceptibility to oxidative attack by altering membrane integrity and fatty acid composition. Since antioxidant enzymes depend on various essential trace elements as selenium, copper and zinc for proper molecular structure and enzymatic activity are potential targets for lead toxicity [45].

There is a positive linear correlation between lead levels in blood (also in kidney or aorta) and the increase in kidney NO concentration that could be explained by a stimulating effect of lead on the activity of $\mathrm{NO}$ synthase that catalyze the formation of $\mathrm{NO}$ and citrulline from L-arginine, $\mathrm{O}_{2}$, and nicotinamide adenine dinucleotide phosphate (NADPH) [46]. It is shown that lead in small doses can directly stimulate the endothelial nitric oxide synthase (eNOS) gene transcription or expression [47].

From the present study, it could be noticed a significant elevation in plasma and renal antioxidant enzymes activity and GSH with reduction in the renal levels of NO and MDA in lead-treated rats on administration of coriander and fennel seeds extracts at the tested doses, this was in accordance with Shaheen et al. [48]; Rabeh and Aboraya [49] and El Baz et al. [50].

Quercetin present in coriander and fennel seeds extracts is recognized to have a strong scavenging activity of oxygen radicals and protection against lipid and protein oxidation by reversing oxidantantioxidant imbalance and regulation of NO bioavailability in serum and kidney [51]. Flavonoids and phenolic compounds present in fennel aqueous extract possess various free radicals scavenging mechanism, e.g. by scavenging or quenching free radicals, by chelating metal ions, or by inhibiting enzymatic systems responsible for the generation of free radicals [52]. Lux and Naidoo [53] stated that the main principal constituents of fennel plants, considerable concentrations of essential trace element such as iron, selenium, manganese and zinc were identified. These are involved in multiple biological processes as constituent of antioxidant enzyme systems. Iron is a cofactor of catalase, which plays a role in antioxidant defense systems by catalyzing the decomposition of hydrogen peroxide [54]. The trace elements selenium (Se), copper $(\mathrm{Cu})$ and zinc $(\mathrm{Zn})$ are important cofactors of antioxidant enzymes such as superoxide dismutase (Cu-SOD, Zn-SOD), glutathione peroxidase (GPX) as well as protein with antioxidant properties, ceruloplasmin (CRL, copper-binding protein). So, coriander and fennel contain a mixture of bioactive compounds as well as essential trace elements could be of value to stimulate the body self defense mechanisms against oxidative stress by the maintenance of glutathione contents.

\section{Conclusion}

Herbs extracts exhibited a significant dose-dependent ameliorative effect against lead inducednephrotoxicity in rats in some parameters such as depletion of serum and renal lead concentration, restoration in the $\delta$ ALAD enzyme activity, normalization of serum creatinine and uric acid with regulation of electrolytes levels in serum and urine, raise enzymatic and non-enzymatic antioxidants levels and decrease the oxidants level in plasma and kidney. 


\section{REFERENCES}

[1] Abd El-Ghany M.A., Ramadan A.M. and Ghozy S.F. Nutraceutical effects of curcuma, ginger, celery, yeast and honey on side effects of gentamicin induced nephrotoxicity in rats, World Appl Sci J. 16 (5): 646- 55 (2012).

[2] Pydi R. Nephroprotective medicinal plants- A review, Int J Univers Pharm Life Sci. 1(2): 26681 (2012).

[3] Manoj Kumar V., Dale W., Prabhakara Rao Y., Sharada R. and Bettaiya R. Protective role of coriandrumsativum seed extract against lead-induced oxidative stress in rat liver and kidney, Curr Trends Biotechnol Pharm. 7 (2):650-64 (2013).

[4] Gonick H.C. Nephrotoxicity of cadmium \& lead, Indian J Med Res. 128:335-52 (2008).

[5] Hamadouche N.A., Slimani M., Merad-Boudia B. and Zaoui C. Reproductive toxicity of lead acetate in adult male rats, Am J Sci Res. 3:38-50 (2009).

[6] Owoeye O. and Onwuka S.K. Lead Toxicity: Effect of Launaeataraxacifolia on the histological and oxidative alterations in rat regio III cornuammonis and cerebellum, Anatomy Journal of Africa. 5(1):783-94 (2016).

[7] Peesa J.P. Nephroprotective Potential of Herbal Medicines: A Review, Asian J Pharm Tech. 3(3):115-8 (2013).

[8] Emamghoreishi M., Khasaki M. and Aazam M.F. Coriandrumsativum: evaluation of its anxiolytic effect in the elevated plus-maze, J Ethnopharmacol. 96: 365 -70 (2005).

[9] Wangensteen H., Samuelsena A.B. and Malterud K.E. Antioxidant activity in extracts from coriander, Food Chem. 88: 293-97 (2004).

[10] Aga M., Iwaki K., Ueda Y., Ushio S., Masaki N., Fukuda S., et al. Preventive effect of Coriandrumsativum (Chinese parsley) on localized lead deposition in ICR mice, J Ethnopharmacol. 77: 203-8 (2001).

[11] Kansal L., Sharma V., Sharma A., Lodi S. and Sharma S.H. Protective role of Coriandrumsativum (coriander) extracts against lead nitrate induced oxidative stress and tissue damage in the liver and kidney in male mice, Int J Appl Biol Pharm. 2(3): 65-83. (2011).

[12] Aboelsoud N.H. Herbal medicine in ancient Egypt, J Med Plants Res. 4(2): 82-86 (2010).

[13] Alexandrovich I., Rakovitskaya O., Kolmo E., Sidorova T. and Shushunov S. The effect of fennel (Foeniculum vulgare) seed oil emulsion in infantile colic: a randomized,placebocontrolled study, Altern Ther Health Med. 9:58-61(2003).

[14] Shaffie M.N., Morsy A.F., Ali G.A. and Sharaf A.H. Effect of Craway, Coriander and Fennel on the structure of kidney and islets of Langerhans in alloxan-Induced diabetic rats: Histological and histochemical study, Researcher. 2 (7): 27-40 (2010).

[15] Koppula $\boldsymbol{S}$. and Kumar $\boldsymbol{H}$. Foeniculum vulgare mill (Umbelliferae) attenuates stress and improves memory in Wister rats, Trop J Pharm Res. 12 (4): 553-8 (2013).

[16] Chatterjee S., Goswami N. and Bhatnagar P. Estimation of Phenolic components and in vitroantioxidant activity of Fennel (Foeniculum vulgare) and Ajwain (Trachyspermumammi) seeds,_Adv Biores. 3 (2): 109 - 18 (2012).

[17] National Research Council (NRC) Nutrient requirements of laboratory animals.4th revised edition. National Academy Press, Washington, chapter (2): 11-79 (1995).

[18] Sadrefozalayi S. and Farokhi F. Effect of the aqueous extract of Foeniculum vulgare (fennel) on the kidney in experimental PCOS female rats, Avicenna J Phytomed. 4 (2):110-7 (2014).

[19] European Food Safety Authority (EFSA) Advice on the EFSA guidance document for the safety assessment of botanicals and botanical preparations intended for use as food supplements, based on real case studies. EFSA Journal. 7:280 (2009).

[20] Batra N., Nehru B. and Bansal M.P. Reproductive potential of male Portan rats exposed to various levels of lead with regard to zinc status, Brit J Nutr. 91: 387-91 (2004).

[21] Subramanian K.S. Determination of metals in biofluids and tissues: sample preparation methods for atomic spectroscopic techniques, Spectrochimica Act. 51: 291-319 (1996).

[22] Beutler E., Duroun O. and Kelly B.M. Improved method for the determination of blood glutathione, J Lab Clin Med. 61:882-8 (1963). 
Dose-Dependent Effect of Coriander (Coriandrum Sativum L.) and Fennel (Foeniculum Vulgare M.) on Lead Nephrotoxicity in Rats

[23] Levesque R. SPSS Programming and Data Management: A Guide for SPSS and SAS Users $4^{\text {th }}$ ed. SPSS Inc, Chicago, IL (2007).

[24] Velaga M.K., Yallapragada P.R., Williams D., Rajanna S. and Bettaiya R. Hydroalcoholic seed extract of Coriandrumsativum (Coriander) alleviates lead-induced oxidative stress in different regions of rat brain, Biol Trace Elem Res. 159(1-3): 351-63(2014).

[25] Flora SIS, Mittal M and Mehta A. Heavy metal induced oxidative stress \& its possible reversal by chelation therapy. Indian J Med Res. 128: 501-23(2008).

[26] Kansal L., Sharma A. and Lodi S. Remedial effect of Coriandrumsativum (coriander) extracts on lead induced oxidative damage in soft tissues of Swiss albino mice, Int J Pharm Sci. 4 (3): 729-36(2012).

[27] Zhou J.R. and Erdman J.W.J.R. Phitic acid in health and disease, Crit Rev Food Sci Nutr. 35:495-508(1995).

[28] Bravo A. and Anacona J.R. Metal complexes of the flavonoid quercetin: antibacterial properties, Trans Met Chem. 26: 20-23 (2001).

[29] Flora G., Gupta D. and Tiwari A. Toxicity of Lead: A Review with Recent Updates, Interdiscip Toxicol. 5(2): 47-58(2012).

[30] Suleman M., Khan A. A., Hussain Z., Zia M. A., Roomi S., Rashid F., Iqbal A. and Ishaq R. Effect of lead acetate administered orally at different dosage levels in broiler chicks, Afr J Environ Sci Technol. 5(12): 1017-26 (2011).

[31] Ramya S. and Prasanna G. Nephroprotective effect of camellia sinensis L. on lead acetate induced male albino rats, Int JPharmTechRes. 5 (2): 511-5(2013).

[32] Taha N., Korshom M., Mandour A., Lebdah M. and Aladham E. Effect of lead toxicity on mineral metabolism and immunological factors in rats, Alexandria Journal of Veterinary Sciences. 39: 64-73(2013).

[33] Farag A.H., Mandy A.K., Abdel-Rahaman G.H. and Osofor M.M. Protective effect of Nigella Sativum seeds against lead induced hepatorenal damage in males rats, J Biol Sci. 10(17): 280916(2007).

[34] Morales A.I., Vicente-Sanchez C., Santiago S.J., Egido J., Mayoral P. and Arevalo M.A. Protective effect of quercetin on experimental chronic cadmium nephrotoxicity in rats is based on its antioxidant properties, Food ChemToxicol. 44: 2092-100(2006).

[35] Odigie I.P., Ladipo C.O., Ettarh R.R. and Izegbu M.C. Effect of chronic exposure to low levels of lead on renal function and renal ultrastructure in Sd rats, Niger J Physiol Sci. 19(1-2): 2732(2004).

[36] KheirEldin A.A., shaheen A.A., Abd el-gawad H.M. and Shehata N.I. Protective effect of taurine and quercetinagainst renal dysfunction associated with the combined use of gentamicin and diclofenac, Indian J Biochem Biophys. 45 332-40(2008).

[37] Aissaoui A., El-Hilaly J., Israily Z.H. and Lyoussi B. Acute diuretic effect of continuous intravenous infusion of an aqueous extract of CoriandrumsativumL. in anesthetized rats, $\mathbf{J}$ Ethnopharmacol. 115, 89(2008).

[38] Saeed M., Amen A., Fahmi A., El Garawani I., Sayed S. The possible protective effect of Coriandrumsativum seeds methanolic extract on hepato-renal toxicity induced by sodium arsenite in albino rats, Journal of Applied Pharmaceutical Science. 4 (12): 044-051(2014).

[39] El Bardai S., Lyoussi B., Wibo M., and Morel N. Pharmacological evidence of hypotensive activity of Marrubium vulgare and Foeniculum vulgare in spontaneously hypertensive rat, Clin Exp Hypertens. 23 (4): 329-43(2002).

[40] Melo E.A., Bion F.M., Filho J.M. and Guerra N.B. In vivo antioxidant effect of aqueous and etheric coriander (Coriandrumsativum L.) extracts, Eur J Lipid Sci Tech. 105: 483 - 7(2003).

[41] Liu C.M., Ma J.Q. and Sun Y.Z. Quercetin protects the rat kidney against oxidative stressmediated DNA damage and apoptosis induced by lead, Environ Toxicol Pharmacol. 30: 26471(2010). 
[42] Reddy Y.A., Chalamaiah M., Ramesh B., Balaji G. and Indira P. Ameliorating activity of ginger (Zingiberofficinale) extract against lead induced renal toxicity in male rats, J Food Sci Technol. 51(5):908-14 (2014).

[43] Elmenofi G.A.M. Bee honey dose-dependently ameliorates lead acetate- mediated hepatorenal toxicity in rats, Life Sci. J. 9(4): 780-8 (2012).

[44] Patrick L. Mercury toxicity and antioxidants: Part I: Role of glutathione and alpha-lipoic acid in the treatment of mercury toxicity, Altern Med Rev. 7: 456-71(2002).

[45] Azoz H.A. and Raafat R.M. Effect of lead toxicity on cytogenisity, biochemical constituents and tissue residue with protective role of activated charcoal and casein in male rats, Aust $\mathbf{J}$ Basic Appl Sci. 6(7): 497-509 (2012).

[46] Gonick H.C., Ding Y., Bondy S.C., Ni Z. and Vaziri N.D. Lead-induced hypertension: interplay of nitric oxide and reactive oxygen species, Hypertension. 30: 1487-92(1997).

[47] Vaziri N.D., Liang K. and Ding $Y$. Increased nitric oxide inactivation by reactive oxygen species in lead-induced hypertension, Kidney Int. 56: 1492-8 (1999).

[48] Shaheen U., Manzoor Z., Khaliq T., Kanwal A., Muhammad F., Hassan A. J., et al. Evaluation of nephron-protective effects of Foeniculum Vulgare Mill, Solanum Nigrum Linn and their mixture against gentamicin-induced nephrotoxicity in albino rabbits, Int J Pharm Sci Rev Res. 25(1): 1-9(2014).

[49] Rabeh N.M. and Aboraya A.O. Hepatoprotective effect of dill (Anethumgraveolens L.) and Fennel (Foeniculum vulgare) oil on hepatotoxic rats, Pak J Nut. 13 (6): 303-9(2014).

[50] El Baz F.K., Salama Z.A., Abdel Baky H.H., Gaafar A.A. Hepatoprotective effect of sweet Fennel (Foenculum vulgare L.) methanol extract against carbon tetrachloride induced liver injury in rats, Int J Pharm Sci Rev Res. 25(2): 194-201(2014).

[51] Kohri S. and Fujii H. 2, 2_-Azobis (isobutyronitrile)-derived alkylperoxylradical scavenging activity assay of hydrophilic antioxidants by employing EPR spin trap method, J Clin Biochem Nutr. 53 (3) 134-8 (2013).

[52] Mojzisova G. and Kuchta M. Dietary flavonoids and risk of coronary heart disease. Physiol Res. 50: 529- 35(2001).

[53] Lux O. and Naidoo D. The assessment of biological variation components of copper, zinc and selenium., J Nutr Biochem. 6(1): 43-47(1995).

[54] Ounjaijean S., Westermarck T., Partinen M., Plonka-Poltorak E., Kaipainen P., Kaski M., et al. Increase in non-transferrin bound iron and the oxidative stress status in epilepsy patients treated using valproic acid monotherapy, Int J Clin Pharmacol Ther. 49(4): 268-7(2011). 